\title{
Ecological limits to terrestrial biological carbon dioxide removal
}

\author{
Lydia J. Smith • Margaret S. Torn
}

Received: 25 May 2012 /Accepted: 23 December 2012 / Published online: 6 February 2013

(C) The Author(s) 2013. This article is published with open access at Springerlink.com

\begin{abstract}
Terrestrial biological atmospheric carbon dioxide removal (BCDR) through bioenergy with carbon capture and storage (BECS), afforestation/reforestation, and forest and soil management is a family of proposed climate change mitigation strategies. Very high sequestration potentials for these strategies have been reported, but there has been no systematic analysis of the potential ecological limits to and environmental impacts of implementation at the scale relevant to climate change mitigation. In this analysis, we identified site-specific aspects of land, water, nutrients, and habitat that will affect local project-scale carbon sequestration and ecological impacts. Using this framework, we estimated global-scale land and resource requirements for $\mathrm{BCDR}$, implemented at a rate of $1 \mathrm{Pg} \mathrm{Cy}^{-1}$. We estimate that removing $1 \mathrm{Pg} \mathrm{C} \mathrm{y}^{-1}$ via tropical afforestation would require at least $7 \times 10^{6}$ ha $^{-1}$ of land, $0.09 \mathrm{Tg} \mathrm{y}^{-1}$ of nitrogen, and $0.2 \mathrm{Tg} \mathrm{y}^{-1}$ of phosphorous, and would increase evapotranspiration from those lands by almost $50 \%$. Switchgrass BECS would require at least $2 \times 10^{8}$ ha of land (20 times U.S. area currently under bioethanol production) and $20 \mathrm{Tg} \mathrm{y}^{-1}$ of nitrogen ( $20 \%$ of global fertilizer nitrogen production), consuming $4 \times 10^{12} \mathrm{~m}^{3} \mathrm{y}^{-1}$ of water. While BCDR promises some direct (climate) and ancillary (restoration, habitat protection) benefits, Pg C-scale implementation may be constrained by ecological factors, and may compromise the ultimate goals of climate change mitigation.
\end{abstract}

\section{Introduction}

Global fossil fuel use emits roughly $8 \mathrm{Pg}$ carbon (C) $\mathrm{y}^{-1}$ to the atmosphere (EIA 2011). Because the oceans and terrestrial biosphere take up only roughly $55 \%$ of these emissions

This article is part of a Special Issue on "Carbon Dioxide Removal from the Atmosphere: Complementary Insights from Science and Modeling" edited by Massimo Tavoni, Robert Socolow, and Carlo Carraro.

Electronic supplementary material The online version of this article (doi:10.1007/s10584-012-0682-3) contains supplementary material, which is available to authorized users.

L. J. Smith $\cdot$ M. S. Torn $(\bowtie)$

University of California, Berkeley, Berkeley, CA, USA

e-mail: MSTorn@lbl.gov

L. J. Smith • M. S. Torn

Earth Sciences Division, Lawrence Berkeley National Laboratory, Berkeley, CA, USA 
(Ballantyne et al. 2012), atmospheric carbon dioxide $\left(\mathrm{CO}_{2}\right)$ concentrations are growing at roughly $2 \mathrm{ppm} \mathrm{y}^{-1}$ (NOAA 2012). Given this trend, strategies for atmospheric carbon dioxide removal (CDR), are being considered for climate change mitigation. One category of CDR, terrestrial biological carbon dioxide removal (BCDR), increases terrestrial reservoirs' carbon uptake and storage by increasing plant productivity and/or carbon residence times, reducing the fraction of emissions that remain airborne, which currently averages $45 \%$. If BCDR could be implemented on the scale of $1 \mathrm{Pg}$ of carbon (C) per year-the magnitude of stabilization wedges used in Pacala and Socolow (2004) - it could contribute substantially to climate change mitigation.

One BCDR approach is bioenergy with carbon capture and storage (BECS). The next generation of bioenergy technology aims to replace current feedstocks such as corn, sorghum, sugarcane, rapeseed, soy, and oil palm with dedicated cellulosic crops (Kszos et al. 2000; Heaton et al. 2008b), such as woody tree species and the grasses switchgrass (Panacum vergatum) and miscanthus (Miscanthus $x$ giganteus) (Lewandowski et al. 2000). These fuel crops can produce usable energy with $<10 \%$ the energy inputs of corn (McLaughlin and Walsh 1998), with lower water and nutrient requirements (Msangi et al. 2007; Heaton et al. 2008a). In addition to offsetting fossil fuel emissions and sequestering carbon stocks in soils and biomass (Tilman et al. 2006), cellulosic BECS using geologic reservoirs could provide a continual flow of carbon out of the atmosphere.

A second BCDR strategy is forestry-based sequestration, which removes atmospheric carbon and stores it in forest biomass by increasing forest area and/or carbon density. Forestry BCDR projects are grouped into three categories: (1) reforestation (planting trees in deforested areas), (2) afforestation (planting trees in historically treeless areas such as grasslands or shrublands), and (3) forest and harvest management. Afforestation and commercial reforestation projects often use monocultures of fast-growing species such as pine and eucalyptus (Wright et al. 2000).

Third, soil carbon sequestration aims to increase soil carbon stocks through land management practices such as reducing agricultural tillage, planting more deeplyrooted species, and incorporating relatively persistent compounds (e.g., biochar) into soil for long-term storage. Soil carbon sequestration is often conceived of as optimizing inputs and plant cover to restore carbon lost from past land use (West and Marland 2002; Brown et al. 2004; Lal 2004); global soils have lost an estimated $230 \mathrm{Pg} \mathrm{C}$ due to land use in the last 10,000 y (Lal 2001), and conventional cultivation decreases soil carbon by 25-50 \% after 30-50 years (Johnson 1992; Post and Kwon 2000).

Many studies of carbon sequestration consider potential co-benefits, such as increased soil fertility, erosion control, habitat improvement, and community development (Cook and Beyea 2000; Silver et al. 2000; Sauerbeck 2001; Paul et al. 2002; West and Marland 2002; Lal 2008). Negative ecological effects deserve detailed analyses as well, but have received less attention than co-benefits. The most comprehensive analysis to-date, the IPCC third assessment report (Kauppi et al. 2001), included the sequestration capacity and potential ecosystem effects of various BCDR strategies, but had a relatively brief treatment of potential negative ecological effects.

Ecological constraints have been identified in individual studies and reports (Schaeffer et al. 2006; van Vuuren et al. 2007; Dornburg et al. 2008; Thomson et al. 2009), but not synthesized or reviewed. This paper offers a systematic overview of the likely ecological and biophysical limits, negative impacts, and resource implications of BCDR implemented at the Pg C y ${ }^{-1}$ scale. 


\section{Ecological considerations}

Much of the literature presents an optimistic view of BCDR. Studies estimate that BECS could sequester as much as $5 \mathrm{Pg} \mathrm{C}$ annually (Azar et al. 2006) or $771 \mathrm{Pg} \mathrm{C}$ cumulatively by 2100 (Lenton and Vaughan 2009). Estimates of afforestation BCDR potential are based on steady-state stocks and land availability over the next 100 years, ranging from a cumulative 1.5 Pg C in California (Brown et al. 2004) to $104 \mathrm{Pg} \mathrm{C}$ globally (Nilsson and Schopfhauser 1995). Maximum soil carbon sequestration estimates, based on past soil carbon losses and land availability over the next 50 years, are as high as 30-60 Pg C (Lal 2004)

These optimistic estimates overlook or downplay a number of ecological considerations. BCDR requires productive land, nutrients, and water, all of which are limited in the global biosphere. In light of such limitations, actual BCDR capabilities likely fall well below the literature estimates, and efforts to maximize carbon sequestration may negatively affect biodiversity and compete with other resource demands. This section discusses these ecological realities in relation to BCDR.

\subsection{Land and productivity}

BCDR depends on increasing and/or utilizing plant productivity, and most strategies require land of at least moderate fertility (except degraded land restoration). The upper bound on large-scale BCDR could be set by available land and its rate of carbon uptake; conversely, large scale BCDR could intensify competition for arable or manageable land.

Large scale expansion of cellulosic crops for BECS may put pressure on food security (Msangi et al. 2007), forest conservation (Danielsen et al. 2009), and other uses of productive land. Such competition is already apparent, and global demands for food are projected to nearly double over the next 50 years (Tilman et al. 2001), increasing the land area needed for both food and biofuel production.

Like bioenergy, forestry and soil-based BCDR face land and productivity constraints and may compete with other land uses. Although some forestry projects provide co-benefits for local communities while sequestering carbon (e.g., agroforestry), others isolate people from ecosystem services, as when commercial plantations prevent local communities from harvesting wood or other forest products (Jindal et al. 2008).

\subsection{Nutrient balance and soil fertility}

Plants require nitrogen, phosphorous, and other elements to fix carbon. Nitrogen limits productivity in many temperate ecosystems, and phosphorous limits productivity in much of the tropics (i.e., adding the nutrient increases productivity) (Herbert and Fownes 1995; Cleveland et al. 2002), so insufficient nitrogen and phosphorous may limit future forest biomass increases (Hungate et al. 2003; Reich et al. 2006). To overcome these limitations, tree plantations are typically fertilized at the nursery and transplant stages (O'Connell 1994), and long-term increased nutrient demands from afforestation can lead to decreased soil nutrient availability (Jackson et al. 2000; Berthrong et al. 2009), soil acidification, (Jobbágy and Jackson 2004), and decreased capacity to retain added nutrients (Berthrong et al. 2009).

Nutrient limitations pertain to BECS as well. Harvesting bioenergy biomass removes nutrients, particularly potassium and other structural components of aboveground plant tissue. While most cellulosic bioenergy grasses require less fertilization than corn or other ethanol feedstocks (Lewandowski et al. 2000), a series of U.S. studies determined optimal 
fertilization rates of 40-120 kg nitrogen $\mathrm{ha}^{-1} \mathrm{y}^{-1}$, with yield improvements realized up to $224 \mathrm{~kg}$ nitrogen $\mathrm{ha}^{-1} \mathrm{y}^{-1}$ (McLaughlin and Adams Kszos 2005).

Mobilizing nutrients for fertilization has negative environmental consequences downstream and downwind. Fertilizer runoff to oceans, rivers, and lakes has led to species composition and food web shifts, eutrophication, toxin formation, and other impacts (Mitsch et al. 2001; Camargo and Alonso 2006). For example, $70 \%$ of the nitrate loading responsible for the large hypoxic zone in the Gulf of Mexico is attributed to agriculture (Rabalais et al. 2002). Furthermore, producing and applying fertilizer requires energy from fossil fuels; such activities have embedded carbon costs that counteract the carbon benefits of increased productivity (Schlesinger 2010).

\subsection{Water}

Plant photosynthesis requires water to fix carbon. Ecosystems consume water, i.e., withdraw water permanently from a catchment, via evaporation and transpiration (evapotranspiration, ET). By altering plant species, density, and productivity, BCDR activities alter ET, seasonal water use patterns, and rooting depth for water use - all of which can affect water quality and flows for other human and ecosystem uses.

Numerous studies have demonstrated that afforestation affects local hydrology (Bosch and Hewlett 1982; Brown et al. 2005; Nosetto et al. 2011). Because replacing grasslands or shrublands with forests increases ET, afforestation projects can lower the water table, reduce streamflow, and decrease watershed water yield (precipitation - ET) (Farley et al. 2005). On average, where studied, afforestation of grasslands and shrublands cuts streamflow by $1 / 3$ to $3 / 4$, often leading to a loss of perennial streamflow in regions where water yield is already low (Farley et al. 2005). In South Africa, a paired catchment experiment saw streams dry up completely 9 and 12 years after eucalyptus and pine afforestation (Lesch and Scott 1997), and similar effects were seen in Argentina (Nosetto et al. 2011). More generally, a $10 \%$ increase in tree cover decreases water yield by $25-40 \mathrm{~mm}$ across a range of ecosystems (Sahin and Hall 1996; Jackson et al. 2000).

By changing the water table and soil texture, forestry projects also affect soil and water salt balance in site-specific ways. In Australia, reforestation is used to reduce salinity; tree growth increases water table depth, reducing infiltration of saline groundwater into surface soils (George et al. 1999). In Argentina's humid grasslands, by contrast, afforestation salinizes soils by using up the thin freshwater lens above saline groundwater (Jobbágy and Jackson 2004).

The amount of water consumed by BECS for energy generation and for carbon capture and storage is two orders of magnitude lower than that used for biomass growth, but this industrial usage requires water diversion, conveyance, and treatment with intensive localized effects (Scown et al. 2011). As with nutrient additions, water infrastructure and groundwater pumping require energy as well, reducing net carbon sequestration gains (Schlesinger 2000).

\subsection{Biodiversity}

Afforestation and bioenergy projects can threaten biodiversity. Recent decades have seen increased conversion of natural forests to pine or eucalyptus monocultures (Zurita et al. 2006), and policy incentives for further land conversion may negatively affect biodiversity (Caparrós and Jacquemont 2003). Bioenergy expansion can directly convert native habitats to cropland or indirectly drive land clearing elsewhere by displacing cropland or rangeland (Cook and Beyea 2000; Lapola et al. 2010). 
How a BCDR project affects biodiversity depends on the native ecosystem type, land use history, planted species, and spatial arrangement of remaining native habitats. Existing research is difficult to synthesize (Barlow et al. 2007), but in many cases, BCDR-type land use reduces biodiversity. Primary forests tend to have higher plant and animal diversity than secondary or plantation forests (Lindenmayer and Hobbs 2004; Zurita et al. 2006; Barlow et al. 2007), and even restored grasslands or forests often have lower biodiversity than nearby native ecosystems (Camill et al. 2004).

\subsection{Non- $\mathrm{CO}_{2}$ climate impacts}

In addition to $\mathrm{CO}_{2}$ emissions, other greenhouse gas emissions, albedo, and latent heat fluxes influence regional and global climate (Diffenbaugh 2009; Georgescu et al. 2009). As a result, non- $\mathrm{CO}_{2}$ climate impacts of BCDR may offset intended climate mitigation.

Fertilizer use in BCDR is an important part of this tradeoff. 1-5\% of global nitrogen fertilizer is converted to nitrous oxide (global warming potential 296 times higher than $\mathrm{CO}_{2}$ ) (De Klein et al. 2006; Solomon et al. 2007; Crutzen et al. 2008). Where quantified, adding manure or inorganic fertilizer, planting legumes, or incorporating crop residues all resulted in nitrous oxide emissions offsetting 75-310\% of the sequestered $\mathrm{CO}_{2}$ (Robertson et al. 2000; Brown et al. 2004; Li et al. 2005).

The energy balance of a given land area is determined primarily by the albedo and ET, associated with plant cover type and productivity (Pielke and Avissar 1990). By altering land cover and land use, BCDR may therefore influence local climate directly, intensifying or counteracting the effects of atmospheric $\mathrm{CO}_{2}$ reduction in site-specific ways (Gibbard et al. 2005). Increases in forest cover generally cause cooling in the tropics where the ET effect dominates (Claussen et al. 2001) and warming in mid- and high-latitudes where the albedo effect is strong (Betts 2000). In temperate latitudes, where substantial bioenergy cultivation may occur, net biophysical effects are difficult to predict (Bonan 2008).

\section{Estimated requirements for $1 \mathrm{Pg} \mathrm{C} \mathrm{y}^{-1}$ sequestration}

The challenge for BCDR as a mitigation measure is implementing it at a meaningful scale. In this section, we estimate resource requirements and ancillary damages associated with $1 \mathrm{Pg}$ $\mathrm{C}^{-1}$ atmospheric carbon removal using either eucalyptus afforestation or switchgrass BECS. Using emissions factors, typical resource inputs, and efficiencies from the literature, we generate order of magnitude estimates of land area requirements, nitrogen $(\mathrm{N})$ and phosphorous $(\mathrm{P})$ applications, water consumption, and nitrous oxide $\left(\mathrm{N}_{2} \mathrm{O}\right)$ emissions.

\subsection{Inputs to the calculation}

We calculated resource requirements using literature values for typical carbon accumulation rates, carbon inputs and emissions from agricultural and silvicultural practices, ecosystemspecific evapotranspiration rates, and industrial processing efficiencies (Table 1). Where the literature offers a range of values for a given process, technology, or ecosystem property, we calculate low and high estimates (equations in Electronic Supplementary Material).

Switchgrass production requires fossil fuel inputs for machinery used in establishment (soil preparation and seed sowing), cultivation, harvest, and transportation to the processing plant (Qin et al. 2006). Fertilizer, pesticides, and herbicides applied during switchgrass production carry additional carbon costs, from fossil fuels used in their manufacture 
Table 1 Literature-derived values used to calculate resource requirements for $1 \mathrm{Pg} \mathrm{C}^{-1} \mathrm{BCDR}$ with tropical eucalyptus afforestation or temperate switchgrass BECS

\begin{tabular}{|c|c|c|c|}
\hline & Units & Value & Value reference(s) \\
\hline \multicolumn{4}{|l|}{ (a) Afforestation } \\
\hline C sequestration capacity ${ }^{\mathrm{a}}$ & $\mathrm{tC} \mathrm{ha}^{-1}$ & $65-195$ & Winjum et al. 1992 \\
\hline \multirow[t]{2}{*}{ Time to reach sequestration capacity } & \multirow[t]{2}{*}{$\mathrm{y}$} & 113 & Silver et al. 2004 \\
\hline & & 158 & $\begin{array}{l}\text { Lugo et al. } 1988, \\
\text { Stape et al. } 2008\end{array}$ \\
\hline \multirow[t]{2}{*}{ Time to reach sequestration capacity } & \multirow[t]{2}{*}{$\mathrm{y}$} & 50 & Winjum et al. 1992 \\
\hline & & 61 & Silver et al. 2004 \\
\hline \multirow[t]{2}{*}{ Nursery $\mathrm{N}$ additions } & \multirow[t]{2}{*}{$(\mathrm{kgN}) \mathrm{ha}^{-1}$} & \multirow[t]{2}{*}{0.22} & Stape et al. 2001 \\
\hline & & & Stape et al. 2010 \\
\hline \multirow[t]{2}{*}{ Nursery $\mathrm{P}$ additions } & \multirow[t]{2}{*}{$(\mathrm{kg} \mathrm{P}) \mathrm{ha}^{-1}$} & \multirow[t]{2}{*}{0.13} & Stape et al. 2001 \\
\hline & & & Stape et al. 2010 \\
\hline \multirow[t]{3}{*}{ Planting $\mathrm{N}$ additions } & \multirow[t]{3}{*}{$(\mathrm{kgN}) \mathrm{ha}^{-1}$} & \multirow[t]{3}{*}{$14-47$} & Stape et al. 2001 \\
\hline & & & Stape et al. 2010 \\
\hline & & & $\begin{array}{l}\text { de Aguiar Ferreira } \\
\text { and Stape } 2009\end{array}$ \\
\hline \multirow[t]{3}{*}{ Planting $\mathrm{P}$ additions } & \multirow[t]{3}{*}{$(\mathrm{kg} \mathrm{P}) \mathrm{ha}^{-1}$} & \multirow[t]{3}{*}{$30-50$} & Stape et al. 2001 \\
\hline & & & Stape et al. 2010 \\
\hline & & & $\begin{array}{l}\text { de Aguiar Ferreira } \\
\text { and Stape } 2009\end{array}$ \\
\hline \multirow{2}{*}{$\begin{array}{l}\text { ET, forested land with MAP } \\
\text { of } 1,250-1,500 \mathrm{~mm}\end{array}$} & \multirow[t]{2}{*}{$\mathrm{mm} \mathrm{y}^{-1}$} & \multirow[t]{2}{*}{1050} & Zhang et al. 2001 \\
\hline & & & Farley et al. 2005 \\
\hline \multirow{2}{*}{$\begin{array}{l}\text { ET, grassland with MAP } \\
\text { of } 1250-1,500 \mathrm{~mm}\end{array}$} & \multirow[t]{2}{*}{$\mathrm{mm} \mathrm{y}^{-1}$} & \multirow[t]{2}{*}{750} & Zhang et al. 2001 \\
\hline & & & Farley et al. 2005 \\
\hline \multicolumn{4}{|l|}{ (b) Switchgrass } \\
\hline Gross photosynthetic uptake & $\mathrm{g} \mathrm{CO}_{2} \mathrm{~kg}^{-1}$ & 1540 & Qin et al. 2006 \\
\hline Production $\mathrm{CO}_{2}$ losses ${ }^{\mathrm{b}}$ & $\%$ & $5.0-8.5$ & Qin et al. 2006 \\
\hline Storage dry biomass losses & $\%$ & 4 & Qin et al. 2006 \\
\hline Gasification/conditioning & $\%$ & 38 & Rhodes and Keith 2005 \\
\hline Carbon capture efficiency & $\%$ & 89 & Rhodes and Keith 2005 \\
\hline Transport/injection losses & $\%$ & $5.9-12$ & Weisser 2007 \\
\hline \multirow[t]{3}{*}{ Dry biomass productivity } & \multirow[t]{3}{*}{$\operatorname{kgha}^{-1} \mathrm{y}^{-1}$} & $5600-7000$ & Thomson et al. 2009 \\
\hline & & 10000 & Heaton et al. 2004 \\
\hline & & $9100-23000$ & $\begin{array}{l}\text { McLaughlin and Adams } \\
\text { Kszos } 2005\end{array}$ \\
\hline \multirow[t]{2}{*}{ Typical $\mathrm{N}$ additions } & \multirow[t]{2}{*}{$\operatorname{kgha}^{-1} \mathrm{y}^{-1}$} & 80 & Kszos et al. 2000 \\
\hline & & & $\begin{array}{l}\text { McLaughlin and Adams } \\
\text { Kszos } 2005\end{array}$ \\
\hline $\mathrm{N}$ converted to $\mathrm{N}_{2} \mathrm{O}$ & $\%$ & 2 & De Klein et al. 2006 \\
\hline ET water consumption & $\mathrm{Lm}^{2} \mathrm{y}^{-1}$ & 750 & Dominguez-Faus et al. 2009 \\
\hline & & & Hickman et al. 2010 \\
\hline IGCC water use & 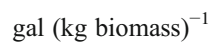 & 0.59 & Mani et al. 2004 \\
\hline & & & Rhodes and Keith 2005 \\
\hline & & & Klett et al. 2007 \\
\hline
\end{tabular}

\footnotetext{
${ }^{a}$ Includes aboveground biomass, belowground biomass, soil carbon, and litter

${ }^{\mathrm{b}}$ Embedded emissions include machinery involved in soil preparation and seed sowing; production, application and transport of agricultural chemicals; harvest and baling or pelletizing; and transport to the processing plant
} 
(Schlesinger 2010), transportation, and application. We subtract the $\mathrm{CO}_{2}$ emissions embedded in these processes from overall carbon sequestration gains. Similarly, carbon lost or embedded via physical biomass losses or energy inputs in the combustion, capture, and storage processes increase the resources required per unit sequestered carbon (Rhodes and Keith 2005; Qin et al. 2006; Weisser 2007).

The switchgrass calculation does not include carbon emissions from direct or indirect land clearing, for our estimate represents the resources required by BECS at steady-state. However, land clearing can seriously affect biodiversity, ecosystem services, and carbon storage over decades or centuries, discussed by Fargione et al. (2008), Searchinger et al. (2008), and Plevin et al. (2010). Additionally, irrigation infrastructure introduces additional carbon emissions. Our calculation also omits carbon emissions reductions from avoided fossil fuel use, addressing BECS with respect to BCDR only, without including its potential value for energy security or as an alternative to fossil fuels to avoid greenhouse gas emissions.

The per-Pg carbon resource demands of afforestation depend on climate, location, tree species, monoculture vs. polyculture, carbon content of the replaced ecosystem (Winjum et al. 1992; Silver et al. 2004), time for the forest carbon to reach steady state, the two ecosystems' relative ET rates (Zhang et al. 2001), and fertilization practices during seedling growth and transplantation (de Aguiar Ferreira and Stape 2009). Due to this high variability, we constrained our estimate to a monoculture eucalyptus plantation in a tropical region with mean annual precipitation of $1,200-1,500 \mathrm{~mm} \mathrm{y}^{-1}$.

Whereas the flow of carbon out of the atmosphere using BECS is theoretically continuous through time, afforestation sequesters carbon by maximizing biomass stocks. As forest biomass reaches steady state, the net carbon uptake rate declines, with little additional CDR after 50 years. Because of this saturation effect, achieving an annual flow of $1 \mathrm{Pg} \mathrm{C} \mathrm{y}^{-1} \mathrm{CDR}$ would require planting new forests annually and protecting existing afforested land (Fig. 1).

\subsection{Results}

For BECS, a field-to-reservoir accounting of carbon flows shows that net sequestration of 1 $\mathrm{Pg} \mathrm{C}$ requires fixing 2.1 Pg C, considering the $\mathrm{CO}_{2}$ losses from farm and transport fossil fuel use, pre-capture storage and processing, and $\mathrm{CO}_{2}$ capture and injection (Fig. 2). We estimate that supporting $2.1 \mathrm{Pg} \mathrm{C} \mathrm{y}^{-1}$ of switchgrass productivity-an increase equal to roughly $3 \%$ of global terrestrial net primary productivity (Haberl et al. 2007) - would use 218-990 Mha of land, 17-79 $\mathrm{Tg} \mathrm{N} \mathrm{y}^{-1}$ fertilizer, and 1.6-7.4 $\times 10^{12} \mathrm{~m}^{3}$ water $\mathrm{y}^{-1}$ from ET and industrial processing (Table 2). Lower fertilization levels should be possible, but no studies of mature switchgrass under repeated harvest management were found to confirm this. This $1 \mathrm{Pg} \mathrm{C} \mathrm{y}^{-1}$ net sequestration would commandeer $\sim 16-75 \%$ of current global $\mathrm{N}$ fertilizer production and 14-65 times the U.S. land area currently under bioethanol production.

To sequester a stock of $1 \mathrm{Pg} \mathrm{C}$ in forest biomass, tropical afforestation projects would cover $6.7-15 \mathrm{Mha}$ (equal to $4 \%$ of global plantation forest area in 2000), apply $2.0-7.7 \times 10^{5}$ $\mathrm{Mg} \mathrm{P}$ and $9-73 \times 10^{4} \mathrm{Mg} \mathrm{N}$ as fertilizer, and consume $1.2-2.7 \times 10^{12} \mathrm{~m}^{3} \mathrm{y}^{-1}$ more water than the grasslands they replace, increasing the percentage of mean annual precipitation consumed via ET on those lands from $50 \%$ to $75 \%$. To a coarse approximation, 50 times this land area must be converted from grass/shrub to silvicultural management to provide an average annual CDR rate of $1 \mathrm{Pg} \mathrm{C} \mathrm{y}^{-1}$ for 50 years. This $\sim 300-750$ Mha land requirement (equal to as much as half the global tropical grassland area) would be accompanied by a cumulative fertilizer demand of $10-15 \times 10^{6} \mathrm{Mg} \mathrm{P}$ and $4.5-15 \times 10^{6} \mathrm{MgN}$ over 50 years, and a water demand $1.2-2.7 \times 10^{12} \mathrm{~m}^{3} \mathrm{y}^{-1}$ greater than grassland. To continue CDR beyond this 

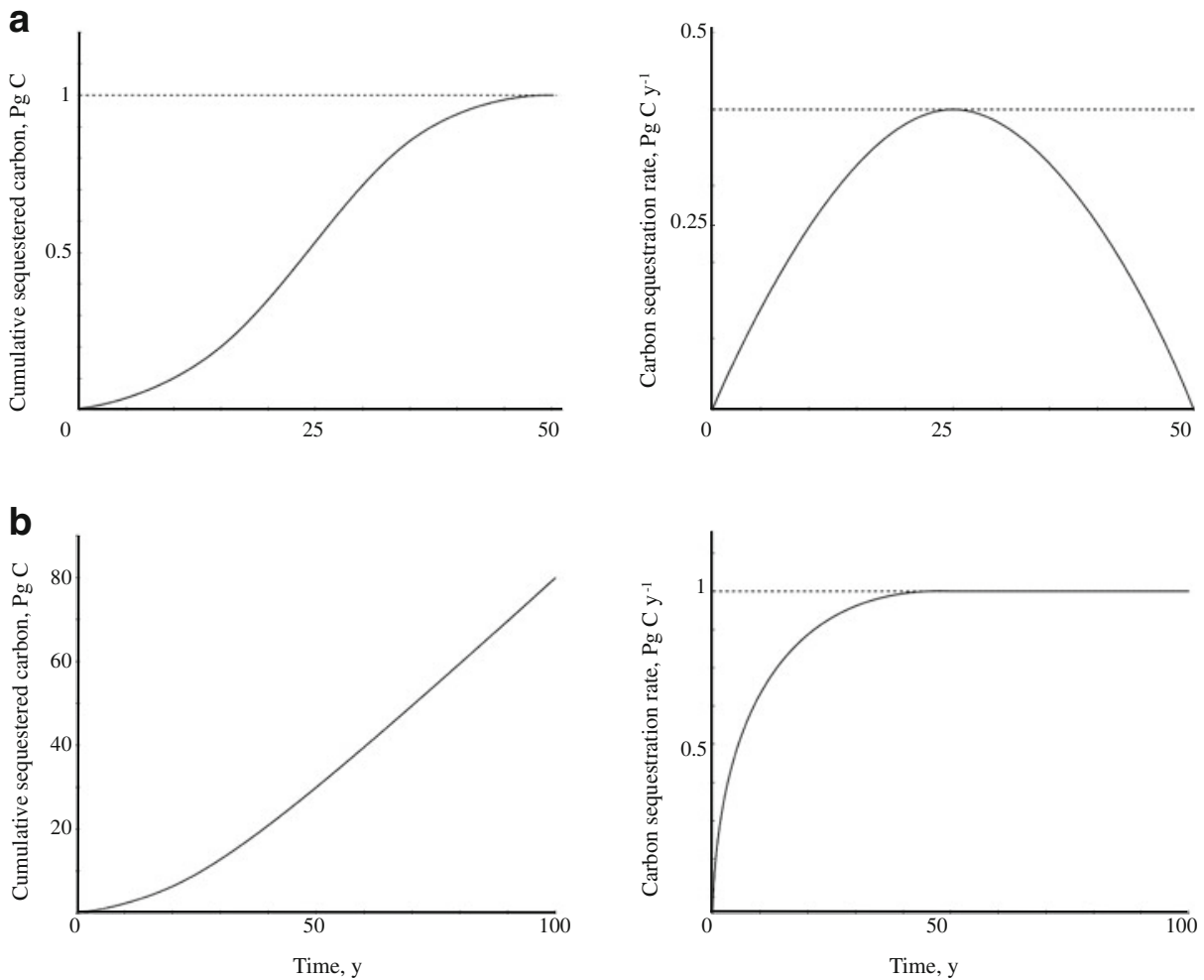

Fig. 1 Afforestation carbon sequestration scenarios. Schematic of carbon sequestration by afforestation under two different land conversion scenarios. a Land with steady state sequestration capacity of $1 \mathrm{Pg} \mathrm{C}$ is afforested in year 1 . The $\mathrm{C}$ accumulation rate peaks at an intermediate year and then saturates after 50 years. $\mathbf{b}$ The same land area is converted each year perpetually. Total carbon accumulation reaches $1 \mathrm{Pg} \mathrm{y}^{-1}$ after 50 years, and continues at that rate as further land conversion continues

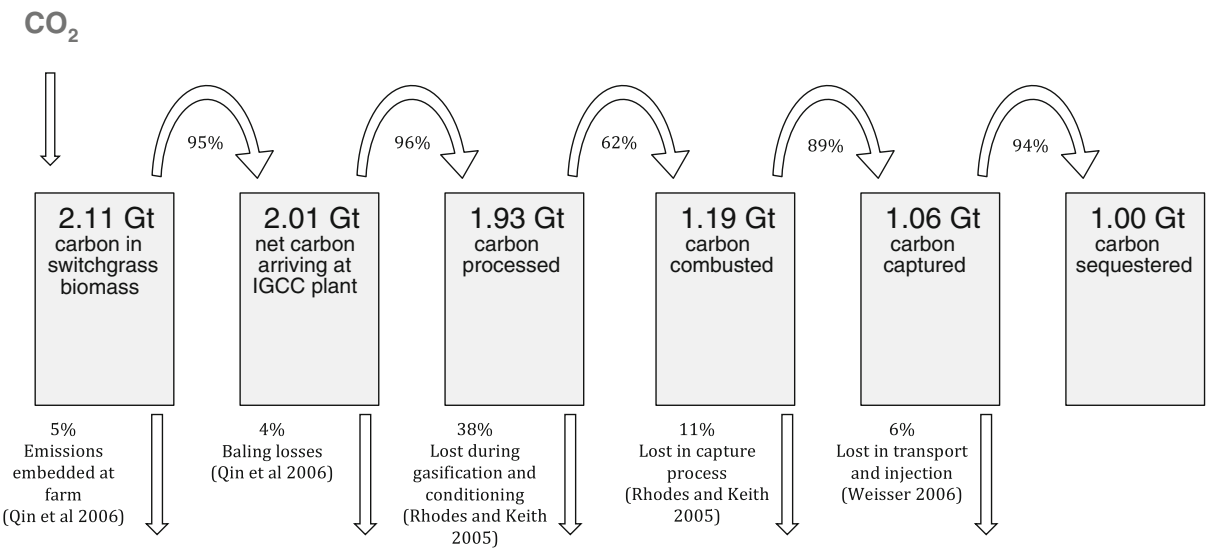

Fig. 2 BECS carbon flow. Schematic of carbon flow, life cycle emissions, and carbon losses during temperate switchgrass production and processing with carbon capture and storage. The percentage values are carbon losses calculated from literature values in Table 1 for an IGCC facility retrofitted to burn biomass only 


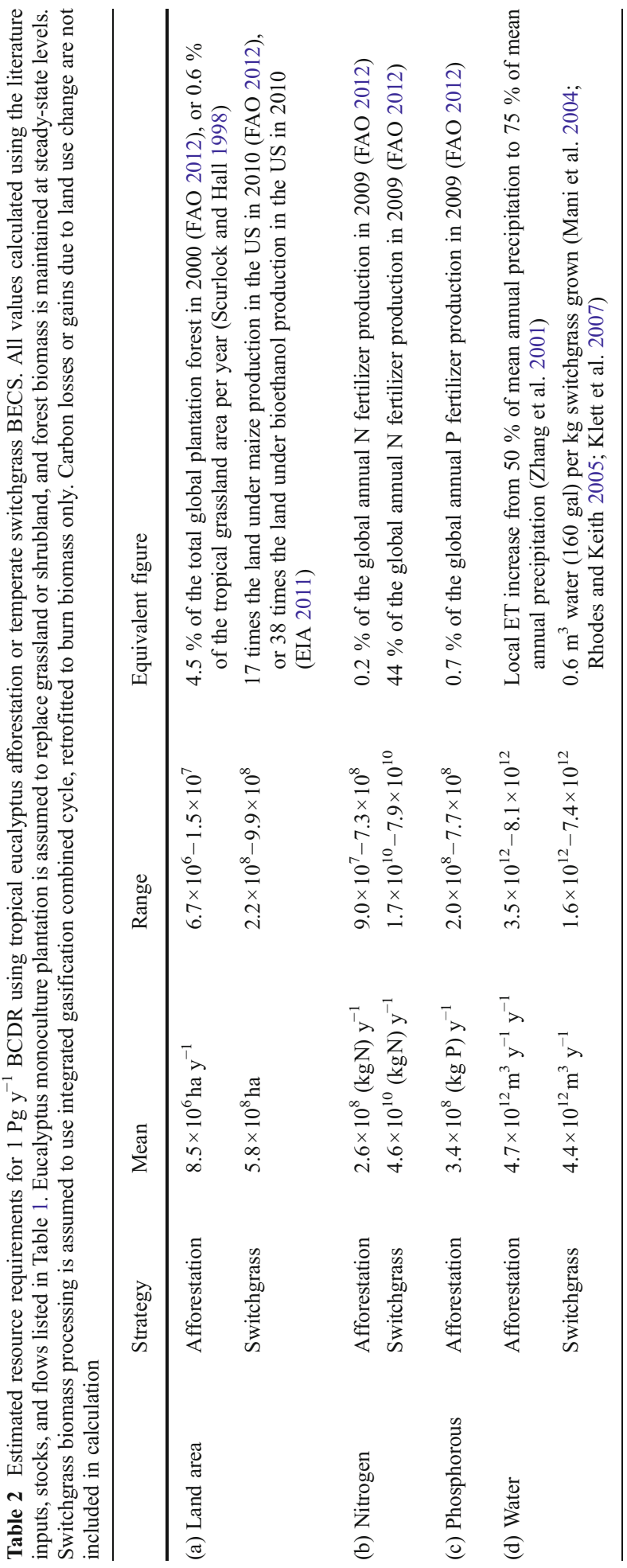


50-year window, additional land conversion would be required, at a rate of 6.7-15 Mha per year, if land of similar fertility were available.

\section{Discussion}

BCDR faces ecological constraints at the local project level and at large scale. The land area required for $1 \mathrm{Pg} \mathrm{C} \mathrm{y}^{-1} \mathrm{BCDR}$ ranges broadly in our calculation, from $\sim 200$ to $\sim 1,000$ Mha, due to literature differences in switchgrass productivity. Average productivities over broad regions are relatively low (Thomson et al. 2009), suggesting that actual land requirements would fall at the high end of our calculated range. A land requirement of as much as 990 Mha for switchgrass or $15 \mathrm{Mha}^{-1}$ for afforestation implies important opportunity costs and impacts on biodiversity and food, fuel, and fiber production. Of the 100 million $\mathrm{km}^{2}$ of productive land area on earth, nearly $40 \%$ is used for agriculture or grazing lands, and scarcity of unexploited arable land constrains agricultural production in many areas (De Fraiture et al. 2008). Humans have already appropriated one third of global net primary productivity, using it primarily as cropland (14\%), pasture (8\%), and managed forest $(3 \%)$ (Vitousek et al. 1986; Haberl et al. 2007). Much of the remaining terrestrial vegetation supports valuable ecosystem services such as water provision, local climate regulation, erosion and flood control, and genetic resource protection (Millennium Ecosystem Assessment 2005).

At the scale relevant to global climate change mitigation, BCDR would entail significant consumption of the world's fertilizer supply, with attendant downstream consequences. This is particularly true for BECS, for which our estimated 17-79 $\mathrm{Tg} \mathrm{N} \mathrm{y}^{-1}$ applied per sequestered $\mathrm{Pg}$ $\mathrm{C} \mathrm{y}^{-1}$ amounts to as much as $75 \%$ of global annual nitrogen fertilizer production. (As with the land area estimate, the low-end estimate is unrealistic at large scale.) Humans have already more than doubled the natural nitrogen fixation rate to over $250 \mathrm{Tg} \mathrm{N}$ per year (Vitousek 1994), and phosphorous fertilizer use increases $1 \%$ annually (FAO 2012).

In some cases, fertilizer availability may constrain large-scale BCDR. Fertilizer phosphorous, for example, is a non-renewable resource whose global use increased 5-fold between 1960 and 2000 (FAO 2012). Prices of mineral fertilizers reflect relative scarcity; phosphorous prices tripled in the last decade and potassium chloride prices quadrupled since 2002 (USDA 2012).

BCDR activities increase water demands in a world where water scarcity constrains plant productivity in many regions (De Fraiture et al. 2008) and a third of humanity lives in waterstressed regions (Vörösmarty et al. 2000). ET water losses from switchgrass production amount to as much as $7 \times 10^{12} \mathrm{~m}^{3} \mathrm{y}^{-1}$ for $1 \mathrm{Pg} \mathrm{C} \mathrm{y}^{-1}$ sequestration, and replacing grasslands with forest increases ET water losses by as much as $50 \%$. If BCDR intensifies pressure on water resources, it could increase tapping of groundwater reserves (Postel et al. 1996), reduce access to clean water (Vörösmarty et al. 2000), divert water from ecosystems, and compete with food demands (Falkenmark 1997).

Scale matters for BCDR, but scaling up may disproportionately impact ecosystems if land suitable for BCDR becomes scarce. If financial incentives spur BCDR expansion, ecosystems and vulnerable societies may pay the cost. Current biodiversity losses, for example, are tightly tied to land use. The fossil record indicates that the past 100 years has seen species extinctions at 100-1,000 times the background rate (Millennium Ecosystem Assessment 2005), and among five drivers of global biodiversity loss between now and 2100 (climate change, land use change, atmospheric $\mathrm{CO}_{2}$ increases, nitrogen deposition, and species introductions), land use change - not climate change - is predicted to be the most important (Sala et al. 2000). 
While this paper provides an estimate of resource requirements for $\mathrm{BCDR}$, the ranges and magnitudes of associated impacts are harder to quantify. Local air and water pollution, reduced biodiversity, and competition with food security and local livelihoods are all context-dependent negative effects that depend on the project, location, land use history, and societal needs. Our abilities to predict and monitor these impacts are limited by model uncertainty (Friedlingstein et al. 2003), insufficient ecological knowledge, unaccounted-for greenhouse gas emissions (Searchinger et al. 2008), measurement difficulties (Baker et al. 2007), and political and economic complexity (Murray 2008).

In conclusion, achieving large-scale BCDR would require project siting that depends on regional resource constraints and localized impacts, as well as management of globally traded resources. Such ecological constraints are underrepresented in the literature, but will limit BCDR's role in climate change mitigation. Our calculated land and nutrient requirements suggest that previous estimates of sustained BCDR potential of 3-5 $\mathrm{Pg} \mathrm{C} \mathrm{y}{ }^{-1}$ by BECS and afforestation were unrealistically high. Even at the scale of $1 \mathrm{Pg} \mathrm{C} \mathrm{y}^{-1}$, either strategy represents a major perturbation to land, water, nitrogen, and phosphorous stocks and flows. Climate change mitigation must be a global priority, but more detailed and comprehensive analyses are needed before pursuing large-scale BCDR.

Acknowledgments We thank Robert Socolow and Massimo Tavoni for facilitating this project and reviewing drafts, John Harte and Michael Cohen for their thoughtful comments, and Andrew Jones for contributions to a presentation of this material. This work was supported by the Director, Office of Science, Office of Biological and Environmental Research, Climate and Environmental Science Division, of the U.S. Department of Energy under Contract No. DE-AC02-05CH11231.

Open Access This article is distributed under the terms of the Creative Commons Attribution License which permits any use, distribution, and reproduction in any medium, provided the original author(s) and the source are credited.

\section{References}

Azar C, Lindgren K, Larson E, Möllersten K (2006) Carbon capture and storage from fossil fuels and biomass - costs and potential role in stabilizing the atmosphere. Clim Chang 74:47-79. doi:10.1007/s10584-0053484-7

Baker JM, Ochsner TE, Venterea RT, Griffis TJ (2007) Tillage and soil carbon sequestration-what do we really know? Agric Ecosyst Environ 118:1-5

Ballantyne AP, Alden CB, Miller JB, Tans PP, White JWC (2012) Increase in observed net carbon dioxide uptake by land and oceans during the past 50 years. Nature 488:70-72. doi:10.1038/ nature 11299

Barlow J, Gardner TA, Araujo IS, Ávila-Pires TC, Bonaldo AB, Costa JE, Esposito MC, Ferreira LV, Hawes J, Hernandez MIM et al (2007) Quantifying the biodiversity value of tropical primary, secondary, and plantation forests. Proc Natl Acad Sci 104:18555

Berthrong ST, Jobbágy EG, Jackson RB (2009) A global meta-analysis of soil exchangeable cations, pH, carbon, and nitrogen with afforestation. Ecol Appl 19:2228-2241. doi:10.1890/08-1730.1

Betts RA (2000) Offset of the potential carbon sink from boreal forestation by decreases in surface albedo. Nature 408:187-190

Bonan GB (2008) Forests and climate change: forcings, feedbacks, and the climate benefits of forests. Science $320: 1444$

Bosch J, Hewlett J (1982) A review of catchment experiments to determine the effect of vegetation changes on water yield and evapotranspiration. J Hydrol 55:3-23 
Brown S, Dushku A, Pearson T, Shoch D, Winsten J, Sweet S, Kadyszewski J (2004) Carbon supply from changes in management of forest, range, and agricultural lands of California. Winrock International for California Energy Commission 144

Brown AE, Zhang L, McMahon TA, Western AW, Vertessy RA (2005) A review of paired catchment studies for determining changes in water yield resulting from alterations in vegetation. J Hydrol 310:28-61

Camargo JA, Alonso Á (2006) Ecological and toxicological effects of inorganic nitrogen pollution in aquatic ecosystems: a global assessment. Environ Int 32:831-849. doi:10.1016/j.envint.2006.05.002

Camill P, McKone MJ, Sturges ST, Severud WJ, Ellis E, Limmer J, Martin CB, Navratil RT, Purdie AJ, Sandel BS et al (2004) Community-and ecosystem-level changes in a species-rich tallgrass prairie restoration. Ecol Appl 14:1680-1694

Caparrós A, Jacquemont F (2003) Conflicts between biodiversity and carbon sequestration programs: economic and legal implications. Ecol Econ 46:143-157. doi:10.1016/S0921-8009(03)00138-1

Claussen M, Brovkin V, Ganopolski A (2001) Biogeophysical versus biogeochemical feedbacks of large-scale land cover change. Geophys Res Lett 28:1011-1014

Cleveland CC, Townsend AR, Schmidt SK (2002) Phosphorus limitation of microbial processes in moist tropical forests: evidence from short-term laboratory incubations and field studies. Ecosystems 5:680691. doi:10.1007/s10021-002-0202-9

Cook J, Beyea J (2000) Bioenergy in the United States: progress and possibilities. Biomass Bioenerg 18:441455

Crutzen PJ, Mosier AR, Smith KA, Winiwarter W (2008) $\mathrm{N}_{2} \mathrm{O}$ release from agro-biofuel production negates global warming reduction by replacing fossil fuels

Danielsen F, Beukema H, Burgess ND, Parish F, Brühl CA, Donald PF, Murdiyarso D, Phalan B, Reijnders L, Struebig $\mathrm{M}$ et al (2009) Biofuel plantations on forested lands: double jeopardy for biodiversity and climate. Conserv Biol 23:348-358

de Aguiar Ferreira J, Stape J (2009) Productivity gains by fertilisation in eucalyptus urophylla clonal plantations across gradients in site and stand conditions. South Forests 71:253-258

De Fraiture C, Giordano M, Liao Y (2008) Biofuels and implications for agricultural water use: blue impacts of green energy. Water Pol 10:67-81

De Klein C, Novoa R, Ogle S, Smith K, Rochette P, Wirth T (2006) Chapter 11: N2O emissions from managed soils, and CO2 emissions from lime and urea application. In: 2006 IPCC guidelines for national greenhouse gas inventories. pp 1-25

Diffenbaugh NS (2009) Influence of modern land cover on the climate of the United States. Clim Dynam 33:945-958

Dominguez-Faus R, Powers SE, Burken JG, Alvarez PJ (2009) The water footprint of biofuels: a drink or drive issue? Environ Sci Technol 43:3005-3010

Dornburg V, Faaij APC, Verweij PA, Langeveld H, van de Ven G, Wester F, van Keulen H, van Diepen K, Meeusen M, Banse M, others (2008) Biomass assessment: assessment of global biomass potentials and their links to food, water, biodiversity, energy demand and economy: main report. Report/WAB. http:// igitur-archive.library.uu.nl/chem/2009-0310-203430/UUindex.html

EIA (2011) Emissions of greenhouse gases in the United States 2009. US Department of Energy, Energy Information Administration

Falkenmark M (1997) Meeting water requirements of an expanding world population. Philos Trans R Soc Lond B Biol Sci 352:929-936

FAO (2012) FAOSTAT. http://faostat.fao.org/site/567/DesktopDefault.aspx?PageID=567\#ancor.

Fargione J, Hill J, Tilman D, Polasky S, Hawthorne P (2008) Land clearing and the biofuel carbon debt. Science 319:1235-1238. doi:10.1126/science.1152747

Farley KA, Jobbagy EG, Jackson RB (2005) Effects of afforestation on water yield: a global synthesis with implications for policy. Glob Chang Biol 11:1565-1576

Friedlingstein P, Dufresne JL, Cox PM, Rayner P (2003) How positive is the feedback between climate change and the carbon cycle? Tellus B 55:692-700. doi:10.1034/j.1600-0889.2003.01461.x

George R, Nulsen R, Ferdowsian R, Raper G (1999) Interactions between trees and groundwaters in recharge and discharge areas-a survey of Western Australian sites. Agr Water Manag 39:91-113

Georgescu M, Lobell D, Field C (2009) Potential impact of US biofuels on regional climate. Geophys Res Lett 36:L21806

Gibbard S, Caldeira K, Bala G, Phillips TJ, Wickett M (2005) Climate effects of global land cover change. Geophys Res Lett 32:1-4

Haberl H, Erb KH, Krausmann F, Gaube V, Bondeau A, Plutzar C, Gingrich S, Lucht W, Fischer-Kowalski M (2007) Quantifying and mapping the human appropriation of net primary production in earth's terrestrial ecosystems. Proc Natl Acad Sci 104:12942-12947. doi:10.1073/pnas.0704243104 
Heaton E, Voigt T, Long SP (2004) A quantitative review comparing the yields of two candidate C4 perennial biomass crops in relation to nitrogen, temperature and water. Biomass Bioenerg 27:21-30

Heaton EA, Dohleman FG, Long SP (2008a) Meeting US biofuel goals with less land: the potential of Miscanthus. Glob Chang Biol 14:2000-2014

Heaton EA, Flavell RB, Mascia PN, Thomas SR, Dohleman FG, Long SP (2008b) Herbaceous energy crop development: recent progress and future prospects. Curr Opin Biotechnol 19:202-209. doi:10.1016/ j.copbio.2008.05.001

Herbert DA, Fownes JH (1995) Phosphorus limitation of forest leaf area and net primary production on a highly weathered soil. Biogeochemistry 29:223-235

Hickman GC, VanLoocke A, Dohleman FG, Bernacchi CJ (2010) A comparison of canopy evapotranspiration for maize and two perennial grasses identified as potential bioenergy crops. GCB Bioenerg 2:157-168

Hungate BA, Dukes JS, Shaw MR, Luo Y, Field CB (2003) Nitrogen and climate change. Science 302:1512

Jackson RB, Schenk HJ, Jobbágy EG, Canadell J, Colello GD, Dickinson RE, Field CB, Friedlingstein P, Heimann M, Hibbard K, Kicklighter DW, Kleidon A, Neilson RP, Parton WJ, Sala OE, Sykes MT (2000) Belowground consequences of vegetation change and their treatment in models. Ecol Appl 10:470-483. doi:10.1890/1051-0761(2000)\%20010\%5B0470:BCOVCA\%5D2.0.CO;2

Jindal R, Swallow B, Kerr J (2008) Forestry-based carbon sequestration projects in Africa: potential benefits and challenges. Nat Resour Forum 32:116-130. doi:10.1111/j.1477-8947.2008.00176.x

Jobbágy EG, Jackson RB (2004) Groundwater use and salinization with grassland afforestation. Glob Chang Biol 10:1299-1312. doi:10.1111/j.1365-2486.2004.00806.x

Johnson DW (1992) Effects of forest management on soil carbon storage. Water Air Soil Pollut 64:83-120

Kauppi P, Sedjo R, Apps M, Cerri C, Fujimori T, Janzen H, Krankina O, Makundi W, Marland G, Masera O, Nabuurs G, Razali W, Ravindranath RH (2001) Technological and economic potential of options to enhance, maintain, and manage biological carbon reservoirs and geo-engineering. In: Climate change 2001: Mitigation. Contribution of Working Group III to the Third Assessment Report of the Intergovernmental Panel on Climate Change. Cambridge University Press, Cambridge, United Kingdom and New York, NY, USA, pp 301-343

Klett MG, Kuehn N, Longanbach JR, Rutkowski M, Schoff RL, Stiegel GJ, Vaysman V, White JS (2007) Power plant water usage and loss study. DOE - NETL.

Kszos LA, Downing ME, Wright LL, Cushman JH, McLaughlin SB, Tolbert VR, Tuskan GA, Walsh ME (2000) Bioenergy feedstock development program status report. ORNL/TM-2000/292, Oak Ridge National Laboratory, Oak Ridge, TN, USA. http://www.ornl.gov/ webworks/cppr/y2001/rpt/108677_.pdf.

Lal R (2001) World cropland soils as a source or sink for atmospheric carbon. In: Advances in agronomy. Academic Press, pp 145-191.

Lal R (2004) Soil carbon sequestration to mitigate climate change. Geoderma 123:1-22

Lal R (2008) Carbon sequestration. Phil Trans Roy Soc Lond B Biol Sci 363:815-830

Lapola DM, Schaldach R, Alcamo J, Bondeau A, Koch J, Koelking C, Priess JA (2010) Indirect land-use changes can overcome carbon savings from biofuels in Brazil. Proc Natl Acad Sci 107:3388-3393. doi:10.1073/pnas.0907318107

Lenton TM, Vaughan NE (2009) The radiative forcing potential of different climate geoengineering options. Atmos Chem Phys 9:5539-5561

Lesch W, Scott DF (1997) The response in water yield to the thinning of Pinus radiata, Pinus patula and Eucalyptus grandis plantations. For Ecol Manage 99:295-307

Lewandowski I, Clifton-Brown J, Scurlock J, Huisman W (2000) Miscanthus: European experience with a novel energy crop. Biomass Bioenerg 19:209-228

Li C, Frolking S, Butterbach-Bahl K (2005) Carbon sequestration in arable soils is likely to increase nitrous oxide emissions, offsetting reductions in climate radiative forcing. Clim Chang 72:321-338. doi:10.1007/ s10584-005-6791-5

Lindenmayer D, Hobbs R (2004) Fauna conservation in Australian plantation forests-a review. Biol Conserv 119:151-168

Lugo AE, Brown S, Chapman J (1988) An analytical review of production rates and stemwood biomass of tropical forest plantations. For Ecol Manage 23:179-200. doi:10.1016/0378-1127(88)90081-3

Mani S, Tabil LG, Sokhansanj S (2004) Grinding performance and physical properties of wheat and barley straws, corn stover and switchgrass. Biomass Bioenerg 27:339-352

McLaughlin SB, Adams Kszos L (2005) Development of switchgrass (Panicum virgatum) as a bioenergy feedstock in the United States. Biomass Bioenerg 28:515-535

McLaughlin SB, Walsh M (1998) Evaluating environmental consequences of producing herbaceous crops for bioenergy. Biomass Bioenerg 14:317-324 
Millennium Ecosystem Assessment (2005) Ecosystems and human well-being: synthesis. Island Press, Washington, DC

Mitsch WJ, Day JW, Gilliam JW, Groffman PM, Hey DL, Randall GW, Wang N (2001) Reducing nitrogen loading to the Gulf of Mexico from the Mississippi river basin: strategies to counter a persistent ecological problem. Bioscience 51:373-388. doi:10.1641/0006-3568(2001)\%20051\%5B0373:RNLTTG\%5D2.0.CO;2

Msangi S, Sulser T, Rosegrant M, Valmonte-Santos R (2007) Global scenarios for biofuels: Impacts and implications for food security and water use. In: 10th Annual Conference on Global Economic Analysis, Purdue University, Indiana

Murray BC (2008) Leakage from an avoided deforestation compensation policy: concepts, empirical evidence, and corrective policy options. Durham, NC, Nicholas Institute for Environmental Policy Solutions, Duke University, 32p

Nilsson S, Schopfhauser W (1995) The carbon-sequestration potential of a global afforestation program. Clim Chang 30:267-293

NOAA (2012) US Dept. of Commerce: Trends in Carbon Dioxide. http:/www.esrl.noaa.gov/gmd/ccgg/ trends/

Nosetto MD, Jobbágy EG, Brizuela AB, Jackson RB (2011) The hydrologic consequences of land cover change in central Argentina. Agric Ecosyst Environ. doi:10.1016/j.agee.2011.01.008

O'Connell AM (1994) Decomposition and nutrient content of litter in a fertilized eucalypt forest. Biol Fertil Soils 17:159-166. doi:10.1007/BF00337749

Pacala S, Socolow R (2004) Stabilization wedges: solving the climate problem for the next 50 years with current technologies. Science 305:968-972

Paul K, Polglase P, Nyakuengama J, Khanna P (2002) Change in soil carbon following afforestation. For Ecol Manage 168:241-257

Pielke RA, Avissar R (1990) Influence of landscape structure on local and regional climate. Landsc Ecol 4:133-155

Plevin RJ, Jones MOHAD, Torn MS, Gibbs HK (2010) Greenhouse gas emissions from biofuels' indirect land use change are uncertain but may be much greater than previously estimated. Environ Sci Technol Columbus 44:8015

Post WM, Kwon KC (2000) Soil carbon sequestration and land-use change: processes and potential. Glob Chang Biol 6:317-327

Postel SL, Daily GC, Ehrlich PR (1996) Human appropriation of renewable fresh water. Science 271:785

Qin X, Mohan T, El-Halwagi M, Cornforth G, McCarl BA (2006) Switchgrass as an alternate feedstock for power generation: an integrated environmental, energy and economic life-cycle assessment. Clean Techn Environ Policy 8:233-249

Rabalais NN, Turner RE, Scavia D (2002) Beyond science into policy: Gulf of Mexico hypoxia and the Mississippi River. Bioscience 52:129-142

Reich PB, Hobbie SE, Lee T, Ellsworth DS, West JB, Tilman D, Knops JMH, Naeem S, Trost J (2006) Nitrogen limitation constrains sustainability of ecosystem response to CO2. Nature 440:922-925. doi:10.1038/nature04486

Rhodes JS, Keith DW (2005) Engineering economic analysis of biomass IGCC with carbon capture and storage. Biomass Bioenerg 29:440-450

Robertson GP, Paul EA, Harwood RR (2000) Greenhouse gases in intensive agriculture: contributions of individual gases to the radiative forcing of the atmosphere. Science 289:1922

Sahin V, Hall MJ (1996) The effects of afforestation and deforestation on water yields. J Hydrol 178:293-309

Sala OE, Stuart Chapin F III, Armesto JJ, Berlow E, Bloomfield J, Dirzo R, Huber-Sanwald E, Huenneke LF, Jackson RB, Kinzig A, Leemans R, Lodge DM, Mooney HA, Oesterheld M, Poff NL, Sykes MT, Walker BH, Walker M, Wall DH (2000) Global biodiversity scenarios for the year 2100. Science 287:1770-1774. doi:10.1126/science.287.5459.1770

Sauerbeck D (2001) CO2 emissions and C sequestration by agriculture-perspectives and limitations. Nutr Cycl Agroecosyst 60:253-266

Schaeffer M, Eickhout B, Hoogwijk M, Strengers B, Van Vuuren D, Leemans R, Opsteegh T (2006) CO2 and albedo climate impacts of extratropical carbon and biomass plantations. Global Biogeochem Cycles 20:GB2020

Schlesinger WH (2000) Carbon sequestration in soils: some cautions amidst optimism. Agric Ecosyst Environ 82:121-127. doi:10.1016/S0167-8809(00)00221-8

Schlesinger WH (2010) On fertilizer-induced soil carbon sequestration in China's croplands. Glob Chang Biol 16:849-850. doi:10.1111/j.1365-2486.2009.01958.x

Scown CD, Horvath A, McKone TE (2011) Water footprint of US transportation fuels. Environ Sci Tech

Scurlock JMO, Hall DO (1998) The global carbon sink: a grassland perspective. Glob Chang Biol $4: 229-233$ 
Searchinger T, Heimlich R, Houghton RA, Dong F, Elobeid A, Fabiosa J, Tokgoz S, Hayes D, Yu T-H (2008) Use of U.S. Croplands for biofuels increases greenhouse gases through emissions from land-use change. Science 319:1238-1240. doi:10.1126/science.1151861

Silver WL, Ostertag R, Lugo AE (2000) The potential for carbon sequestration through reforestation of abandoned tropical agricultural and pasture lands. Restor Ecol 8:394-407. doi:10.1046/j.1526100x.2000.80054.x

Silver WL, Kueppers LM, Lugo AE, Ostertag R, Matzek V (2004) Carbon sequestration and plant community dynamics following reforestation of tropical pasture. Ecol Appl 14:1115-1127

Solomon S, Qin D, Manning M, others (2007) Technical summary. In: Climate change 2007: the physical science basis. Contribution of Working Group 1 to the Fourth Assessment Report of the Intergovernmental Panel on Climate Change. Cambridge University Press, Cambridge, UK and NY, USA, pp 19-91

Stape JL, Gonçalves JLM, Gonçalves AN (2001) Relationships between nursery practices and field performance for Eucalyptus plantations in Brazil. New Forest 22:19-41

Stape JL, Binkley D, Ryan MG (2008) Production and carbon allocation in a clonal Eucalyptus plantation with water and nutrient manipulations. For Ecol Manage 255:920-930

Stape JL, Binkley D, Ryan MG, Fonseca S, Loos RA, Takahashi EN, Silva CR, Silva SR, Hakamada RE, Ferreira JM et al (2010) The Brazil eucalyptus potential productivity project: influence of water, nutrients and stand uniformity on wood production. For Ecol Manage 259:1684-1694

Thomson A, Izaurralde R, West T, Parrish D, Tyler D, Williams J (2009) Simulating potential switchgrass production in the United States. Pacific Northwest National Laboratory, Richland, WA

Tilman D, Fargione J, Wolff B, D'Antonio C, Dobson A, Howarth R, Schindler D, Schlesinger WH, Simberloff D, Swackhamer D (2001) Forecasting agriculturally driven global environmental change. Science 292:281

Tilman D, Hill J, Lehman C (2006) Carbon-negative biofuels from Low-input high-diversity grassland biomass. Science 314:1598-1600. doi:10.1126/science.1133306

USDA (2012) ERS/USDA data - fertilizer use and price. http://www.ers.usda.gov/Data/FertilizerUse/

van Vuuren DP, den Elzen MGJ, Lucas PL, Eickhout B, Strengers BJ, van Ruijven B, Wonink S, van Houdt R (2007) Stabilizing greenhouse gas concentrations at low levels: an assessment of reduction strategies and costs. Clim Chang 81:119-159

Vitousek PM (1994) Beyond global warming: ecology and global change. Ecology 75:1861. doi:10.2307/ 1941591

Vitousek PM, Ehrlich PR, Ehrlich AH, Matson PA (1986) Human appropriation of the products of photosynthesis. Bioscience 36:368-373. doi:10.2307/1310258

Vörösmarty CJ, Green P, Salisbury J, Lammers RB (2000) Global water resources: vulnerability from climate change and population growth. Science 289:284

Weisser D (2007) A guide to life-cycle greenhouse gas (GHG) emissions from electric supply technologies. Energy 32:1543-1559

West TO, Marland G (2002) A synthesis of carbon sequestration, carbon emissions, and net carbon flux in agriculture: comparing tillage practices in the United States. Agric Ecosyst Environ 91:217-232. doi:10.1016/S0167-8809(01)00233-X

Winjum JK, Dixon RK, Schroeder PE (1992) Estimating the global potential of forest and agroforest management practices to sequester carbon. Water Air Soil Pollut 64:213-227

Wright JA, DiNicola A, Gaitan E (2000) Latin American forest plantations: opportunities for carbon sequestration, economic development, and financial returns. J For 98:20-23

Zhang L, Dawes W, Walker G (2001) Response of mean annual evapotranspiration to vegetation changes at catchment scale. Water Resour Res 37:701-708

Zurita G, Rey N, Varela D, Villagra M, Bellocq M (2006) Conversion of the Atlantic Forest into native and exotic tree plantations: Effects on bird communities from the local and regional perspectives. For Ecol Manage 235:164-173 